\title{
SCREENING OF PLANTS AND PLANT EXTRACTS FOR REPELLENCY TO TINEA DUBIELLA, A MAJOR NEW ZEALAND WOOL PEST
}

\author{
P.J. GERARD and L.D. RUF
}

Ruakura Agricultural Centre, Private Bag, Hamilton

\section{SUMMARY}

Twenty-two introduced and 21 native plants were screened for repellent activity against the case-bearing clothes moth Tinea dubiella, an important pest of woollen carpets. Repellency was assessed using adult moths in a two-way choice bioassay. Species with a strong influence on oviposition were identified, the most active being lemon verbena (Aloysia triphylla), french marigold (Tagetes patula), coriander (Coriandrum sativum), southernwood (Artemisia abrotanum), pyrethrum daisy (Chrysanthemum cinerariifolium) pennyroyal (Mentha pulegium), ngaio (Myoporum laetum) and porokaiwhiria (Hedycarya arborea).

Keywords: insect repellents, Tinea dubiella, plant extracts

\section{INTRODUCTION}

Aromatic herbs have been used over the centuries to keep clothing fragrant and free from damage by clothes moths. Southernwood (Artemisia abrotanum) has an ancient reputation as an effective moth repellent and is known by the French as 'Garderobe'. Lavender-filled sachets are still common even though present day householders do not know that their forebears used them as moth repellents. However, there is little scientific evidence to support these 'old wives tale' control methods.

Insect repellents occurring in plants may have commercial application, either as crude plant extracts or as synthetic derivatives of identified compounds. They could be used where householders do not wish to use synthetic insecticides, or where insecticide use in industrial processes is restricted because of environmental problems. Natural repellents could be used to protect items such as wall hangings, tapestries and woollen garments. As wool pests are also stored product pests, repellents could be used to protect cereal foodstuffs.

The aim of the work reported in this paper was to assess if herbs with reputed repellent properties showed significant activity against the case-bearing clothes moth Tinea dubiella and to screen a selection of aromatic New Zealand plant species for similar activity.

\section{MATERIALS AND METHODS}

The plant species tested are listed in Tables 1 and 2. All plant material was tested in a dried form. In the past, herbs were tied up in bunches and hung to dry in a well ventilated place. Modern commercial products are oven or freeze-dried. The chemical reaction within the plant tissues could differ with the drying method used and influence the outcome. Therefore the method used combined old with new. Freshly gathered plant material was hung in bunches under the eaves of a building, out of direct sunlight until well wilted. It was then spread evenly and thinly on a mesh tray and dried at $65^{\circ} \mathrm{C}$ until the leaves were brittle and could be rubbed off the stems. The dried material was stored in glass jars.

To test the dried plant material, small sachets were made consisting of $50 \mathrm{mg}$ of material folded in a $6 \times 10 \mathrm{~cm}$ single ply piece of 'Snowtex' tissue and held with a staple.

The repellency bioassays were carried out in $3.5 \mathrm{~cm}$ diameter by $21 \mathrm{~cm}$ transparent tubes constructed from acetate sheets. Two carpet squares $\left(2.5 \mathrm{~cm}^{2}\right.$ cut pile containing no insect proofing agent) were stapled to the inner surface of the tube, one at either end.

Proc. 44th N.Z. Weed and Pest Control Conf. 1991: 205-208 
Completely covered under one of these squares was the test sachet. The tube ends were then covered with coarse gauze held in place with a rubber band. Ten replicates (tubes) were set up for each treatment

An $X$ had been cut in the centre of each acetate tube to allow the insertion of a glass vial containing a pair of newly emerged $T$. dubiella adults collected from the laboratory colony. Once the moths left the vial, it was removed.

Tubes were laid about $3 \mathrm{~cm}$ apart in open plastic mesh fruit trays which allowed free air movement. The tubes were alternated so that test ends were not adjacent. The trays containing the tubes were stacked, covered so light would not be a factor, and placed in an airy situation.

Tubes were inspected daily and adult position recorded. After 1 week, the number and position of eggs laid in the tubes were assessed. Most eggs were laid on or against the carpet squares. Those laid on the tube floor apart from the carpet squares were counted separately then included in the tube total.

Ethanol extracts were made of those plant species that showed significant repellency in sachet form. Two grams of dried plant material was ground with a pestle and mortar, soaked in $20 \mathrm{ml}$ of $95 \%$ ethanol for 20 minutes then filtered. Using an electronic pipettor, $100 \mathrm{ul}$ was applied to each of ten $2.5 \mathrm{~cm}^{2}$ squares of filter paper and allowed to dry at room temperature. These were then used in the repellency bioassay as above, with the filter paper squares fitted neatly under the test carpet squares.

Ethanol extracts of fresh material from some plant species were made also. In these extracts $5 \mathrm{gm}$ of fresh material was used and soaked for 10 minutes only. Otherwise the method was as above.

Standard errors were calculated for the mean percentage for each treatment. As this was an initial screening, further tests for statistical significance between treatments were not relevant.

\section{RESULTS AND DISCUSSION}

The repellency effects of the plant species tested, as indicated by eggs laid on the control carpet squares expressed as a percentage of total eggs laid, are presented in Tables 1 and 2. A high percentage laid on the control square indicates repellency by the test treatment to adult females. The results for egg placement were reinforced by the adult position data and examples are given in Table 3. High numbers of moths on control compared to treatment carpet squares gave corresponding high percentages of eggs on the control squares. Observations indicated that males appeared to be less affected than the females.

The screening of the sachets of dried plant material confirmed the 'old wives tales' concerning the ability of selected plant species to deter clothes moths. Plant with reputations for moth repellency such as lavender and southernwood caused over $80 \%$ of eggs to be deposited on control carpet squares. It was interesting to note that the seed heads of lavender showed significant repellency, not the leaves. Many of the other introduced plants evaluated are those used by gardeners looking for natural means of controlling pests (Webb 1988). The aromatic compounds produced by these plants is thought to protect nearby plants from infestation. Those amongst this group to perform well against the case-bearing clothes moth were catnip, pennyroyal, coriander, pyrethrum daisy and french marigold. The powerful odour of lemon verbena was the most effective of all. None of the onion family were screened as it was not envisaged that people would wish their winter woollies to be imbued with the fragrance of garlic.

Most of the introduced plants tested have a reputation in the popular literature for insect repellency whereas the native plants were choosen mainly because they are aromatic. An infusion made from the leaves of ngaio has been reported to be used by the Maori to prevent sandfly and mosquito attack (Kirk 1989) and this study demonstrates its repellency to clothes moth. Plant species related to kohekohe, kawakawa, tutunawa and horopito produce insecticidal compounds (Brooker et al 1981) but none showed strong repellency. Repellent properties similar to that of ngaio were also detected for porokaiwhiria, manuka, wharungi, kiwaka and ruakawa. 
TABLE 1: Influence of introduced plant samples on the deposition of eggs on control carpet squares by Tinea dubiella, expressed as a percentage of the total eggs laid.

\begin{tabular}{lccc}
\hline & \multicolumn{3}{c}{ Percentage of eggs on control \pm SE } \\
\cline { 2 - 4 } & Dried Sachet & Fresh extra & Dried extra \\
\hline Blue gum (Eucalyptus globulus) & $84 \pm 11$ & & $69 \pm 12$ \\
Borage (Borago officinalis) & $77 \pm 11$ & & \\
Catnip (Nepeta cataria) & $82 \pm 1$ & $58 \pm 15$ & $50 \pm 10$ \\
Coriander (Coriandum sativum) & $89 \pm 3$ & & $84 \pm 9$ \\
Cotton lavender (Santolina chamaecyparissus) & $85 \pm 12$ & $68 \pm 16$ & $57 \pm 12$ \\
Curry plant (Helichrysum) & $75 \pm 10$ & & \\
Feverfew (Chrysanthemum parthenium) & $55 \pm 13$ & $63 \pm 12$ & \\
French marigold (Tagetes patula) & $89 \pm 6$ & $75 \pm 8$ & $80 \pm 6$ \\
Lavender (Lavandula augustifolia) (leaves) & $63 \pm 13$ & & $64 \pm 9$ \\
Lavender (Lavandula augustifolia) (heads) & $81 \pm 8$ & & \\
Lavender (Lavandula stoechas) (Spanish) & $49 \pm 10$ & & \\
Lemon verbena (Aloysia triphylla) & $94 \pm 4$ & $75 \pm 8$ & $70 \pm 10$ \\
Lion' ear (Leonotus leonurus) & $71 \pm 9$ & & \\
Melaleuca sp & $54 \pm 9$ & & \\
Mexican marigold (Tagetes lucida) & $65 \pm 10$ & & \\
Pennyroyal (Mentha pulegium) & $87 \pm 6$ & $83 \pm 5$ & $50 \pm 8$ \\
Pot marigold (Calendular officinalis) & $65 \pm 8$ & $55 \pm 17$ & \\
Pyrethrum daisy (Chrysanthemum cinerariifolium) & $85 \pm 9$ & & $59 \pm 13$ \\
Smartweed (Polygonum hydropiper) & $70 \pm 9$ & & \\
Southernwood (Artemisia abrotanum) & $88 \pm 5$ & $54 \pm 12$ & $67 \pm 9$ \\
Sweet basil (Ocimum basilicum) & $56 \pm 9$ & & \\
Tansy (Tanacetum vulgare) & $74 \pm 11$ & & \\
Wormwood (Artemisia absinthium) & $67 \pm 10$ & $60 \pm 11$ & \\
\hline
\end{tabular}

TABLE 2: Influence of native plant samples on deposition of eggs on control carpet squares by $T$. dubiella, expressed as a percentage of the total eggs laid.

\begin{tabular}{|c|c|c|c|}
\hline & \multicolumn{3}{|c|}{ Percentage of eggs on control $\pm \mathrm{SE}$} \\
\hline & Dried Sachet & Fresh extra & Dried extra \\
\hline Horopito (Pseudowintera axillaris) & $66 \pm 12$ & · & \\
\hline Kahikatea (Podocarpus dacrydiodes) & $67 \pm 12$ & & \\
\hline Kanuka (Leptospermum ericoides) & $63 \pm 12$ & & \\
\hline Kawakawa (Micropiper excelsum) & $69 \pm 9$ & & \\
\hline Kawaka (Libocedrus plumosa) & $79 \pm 10$ & & $63 \pm 11$ \\
\hline Kohekohe (Dysoxylum spectabile) & $76 \pm 13$ & & \\
\hline Kohia (Passiflora tetrandra) & $72 \pm 14$ & & \\
\hline Koromiko (Hebe salicifolia) & $49 \pm 14$ & & \\
\hline Kotukutuku (Fushia excorticata) & $63 \pm 11$ & & \\
\hline Mahoe (Melicytus ramiflorus) & $69 \pm 11$ & & \\
\hline Mairehau (Phebalium nudum) & $57 \pm 11$ & & $65 \pm 14$ \\
\hline Mangeao (Litsea calicaris) & $65 \pm 11$ & & \\
\hline Manuka (Leptospermum scoparium) & $80 \pm 9$ & & $55 \pm 10$ \\
\hline Ngaio (Myoporum laetum) & $85 \pm 13$ & $67 \pm 11$ & $82 \pm 5$ \\
\hline Porokaiwhiri (Hedycarya arborea) & $85 \pm 5$ & & $75 \pm 9$ \\
\hline Raukawa (Pseudopanax edgerleyi) & $78 \pm 12$ & & $49 \pm 9$ \\
\hline Tarata (Pittosporum eugenoides) & $63 \pm 14$ & & \\
\hline Rimu (Dacrydium cupressinum) & $53 \pm 8$ & $65 \pm 9$ & \\
\hline Totara (Podocarpus totara) & $64 \pm 12$ & & \\
\hline Tutunawai (Polygonum decipiens) & $67 \pm 12$ & & \\
\hline Wharangi (Melicope ternata) & $79 \pm 11$ & & $75 \pm 11$ \\
\hline
\end{tabular}


TABLE 3: Percentage of adult moths observed on test (dried sachet) and control carpet samples over 5 days $( \pm$ SE).

\begin{tabular}{lcc}
\hline & Test & Control \\
\hline Coriander & $24 \pm 10$ & $60 \pm 11$ \\
Lemon verbena & $14 \pm 8$ & $66 \pm 11$ \\
Pennyroyal & $12 \pm 7$ & $46 \pm 11$ \\
Southernwood & $9 \pm 6$ & $54 \pm 11$ \\
Kawakawa & $20 \pm 9$ & $56 \pm 11$ \\
Ngaio & $16 \pm 8$ & $49 \pm 11$ \\
Porokaiwhiri & $18 \pm 9$ & $58 \pm 11$ \\
\hline
\end{tabular}

This was an initial screening and apart from catnip, in which the active ingredient is thought to be nepetalactone (Eisner 1964), not enough is known of the biochemistry of the active plant species to speculate on the repellent components. The ethanol extracts were undertaken as a first step towards identification. If the compound was quite volatile, it was probable that it would have evaporated from the filter paper squares in a matter of hours and thus the moth bioassay would be unlikely to show an effect. Also, the active agent may not be soluble in ethanol. Nevertheless, extracts of lemon verbena, french marigold, pennyroyal, coriander and ngaio showed significant activity.

During the extraction of french marigold, an error was made in weighing and the resulting extract tested was only a tenth of the desired concentration. When the bioassay was repeated with the correct concentration, the results were identical. This indicates that the extract contained one or more substances that were intrinsically repellent, and the results were not due just to the strength of the odour.

\section{CONCLUSIONS}

Dried samples of a range of both introduced and native plants were shown to repell adults of the case-bearing clothes moth and significantly influence egg placement. Ethanol extracts of a number of species contained an active component.

\section{ACKNOWLEDGEMENTS}

The authors wish to thank Hugh Oliver, Ruakura Agricultural Centre and Katherine Beasley, Hamilton Gardens, for providing plant samples and Barbara Dow, Ruakura Agricultural Centre, for statistical analysis of data.

\section{REFERENCES}

Eisner, T., 1964. Catnip: its raison d'etre. Science 146: 1318-20.

Kirk, T., 1889. The Forest Flora of New Zealand. 142 pl. 345 p. Government Printer, Wellington.

Brooker, S.G., Cambie, R.C. and Cooper, R.C., 1981. New Zealand Medicinal Plants. 1.17 p. Heinemann Publishers, Auckland.

Webb, A., 1988. Natural means of pest control. N.Z. Gardener. 44: 38-40. 